Sheffield

Hallam

University
Centre for

Regional Economic

and Social Research

\title{
The productivity of industries and places
}

Christina Beatty

Steve Fothergill 


\title{
THE PRODUCTIVITY OF INDUSTRIES AND PLACES
}

\author{
Christina Beatty and Steve Fothergill \\ Centre for Regional Economic and Social Research \\ Sheffield Hallam University
}

July 2020 


\section{Summary}

This report explores the variations in productivity within industries across UK sub-regions. It brings together official statistics on output and employment to provide a fine-grain view at the local level and presents a range of measures of productivity.

- Although overall levels of output per head and output per job vary a great deal between sub-regions, the differences in the estimated efficiency of production - after adjusting for the mix of industries, occupations and hours worked - are a great deal smaller

- Output (GVA) per job in some sectors of the economy, especially public services, varies only modestly between sub-regions but in other sectors there are big differences between places

- The sub-regions with the highest overall GVA per job have high productivity in most component parts of their economy, and where overall GVA per job is lowest it is generally low in most sectors

- Overall, however, there are large industry-by-industry differences in GVA per job, relative to the national average, in just about all areas. These differences owe something to the local occupational mix but this is a small factor.

The report argues that the evidence on the variations in productivity between industries and places is complex and does not lend itself to a single explanation. Structural factors such as the detailed mix of activities appear to play a significant role. Wage levels may be an influence on differences between places and underlying differences in efficiency may also be a factor.

The report concludes that 'productivity' should not be confused with 'efficiency', that an understanding of the complexity of local productivity is required, and that within the framework of measures to level-up the UK nations and regions, interventions need to be tailored industry by industry, place by place.

\section{Acknowledgement}

This research was financed by Research England's Strategic Priorities Funding. 


\section{THE PRODUCTIVITY OF INDUSTRIES AND PLACES}

\section{Introduction}

This report explores the variations in productivity within industries across different parts of the UK. That there are substantial differences in overall productivity between places, measured by Gross Value Added (GVA) per head or per job, is well established and how to rectify these differences preoccupies much government thinking. The report drills down beyond the aggregate figures to look at whether these local differences are consistent across all industries or driven by just a few prominent sectors.

At the present time concerns about productivity have at least temporarily been submerged by the recession created by the coronavirus crisis, which has also highlighted how the 'social value' of jobs is not necessarily the same as their 'monetary value' measured by GVA. However, as the UK emerges from the crisis there is no reason to suppose that the big local and regional differences in productivity, measured by GVA, will have gone away. Indeed, the post-crisis world will inherit much the same capital stock, workforce and inf rastructure that was previously in place across the country - and with it, no doubt, much the same gaps in productivity.

The report has its roots in two earlier studies. In a 2019 report ${ }^{1}$ we challenged the way that local differences in productivity are conventionally measured, presenting a range of indicators from 'output per head' and 'output per job' through to a new measure of the 'efficiency' of production in each area which adjusted for the local mix of industries and occupations. The conclusion of this exercise was striking: despite the big differences across the country in output per head and per job, the differences in the efficiency of production across the UK appear to be far more modest.

A second report in May $2020^{2}$ took the analysis of several steps further in the context of Sheffield City Region. This looked at trends over time in various measures of productivity, at the variation between local authorities within the sub-region, and at the differences between industries.

In the present report we deploy the methods piloted in the Sheffield City Region study to look at the variations in productivity between industries across all the sub-regions of the UK.

\footnotetext{
${ }^{1}$ C Beatty and S Fothergill (2019) Local Productivity: the real differences across UK cities and regions, CRESR, Sheffield Hallam University.

${ }^{2}$ C Beatty and S Fothergill (2020) Productivity in Sheffield City Region, CRESR, Sheffield Hallam University.
} 


\section{Alternative measures of productivity}

It is useful to begin by looking at the overall variation in productivity between sub-regions. For England, the sub-regions we use are the 38 Local Enterprise Partnership areas. For Scotland and Wales, we use NUTS2 regions (5 in Scotland, 2 in Wales) and Northern Ireland is treated as a single unit.

For each sub-region we present a range of indicators of productivity, each measuring a slightly different thing. This is the approach we followed in our 2019 report, using official data for 2017, and here all the figures have been updated to 2018.

\section{Gross Value Added (GVA) per head}

This is our starting point. GVA per head is the value of production in an area in relation to its population. GVA per head should not be confused with productivity in the sense of 'efficiency' or 'output per job' but it is a legitimate and useful measure of the value of economic activity that takes place in an area in relation to its resident population. Its close relative, GDP per head, is used by the EU to allocate funds for regional development, including substantial funding to the UK up to the end of 2020. The GVA figures we use, and the population data, come from the Office for National Statistics (ONS).

\section{GVA per head less imputed rent}

This is a measure of productivity that strips out the small part of GVA that is not the result of the input of labour. 'Imputed rent' is the value of housing services accruing to owner-occupiers - in effect, the rent they would have had to pay if they had not owned their property - and is conventionally included in GVA and GDP, especially to facilitate international comparisons, but it distorts comparisons of productivity between local areas within the UK because of variations in housing tenure and costs. We therefore exclude imputed rent from all the further measures of GVA described below. The figures on imputed rent come from ONS.

\section{GVA per 16-64 year old}

This expresses GVA in relation to the resident working age population rather than in relation to the population as a whole. This is relevant because different parts of the UK have different proportions of the population above and below working age and, because most under-16 and most-over 65 don't participate in the labour market, it makes sense to look at production in relation to the working age population. The population data again comes from ONS. 
Not all working-age residents are in work of course, and some over-65s remain in employment. Expressing GVA in relation to the employed resident population takes account of the differences in employment rates across the country. In practice the main working-age groups not engaged in paid employment are students, men and women out of the labour market on disability benefits, and women at home with children. Prior to the coronavirus crisis, the unemployed have for a number of years tended to be a smaller group. Estimates of the employed resident population (aged $16+$ ) in each area come from the UK's Annual Population Survey.

\section{GVA per filled job}

GVA per filled job is one of two ONS measures of local productivity (the other is GVA per hour worked). The GVA figures here are taken from ONS but exclude imputed rent. The jobs are those located in the area and this measure of productivity therefore adjusts for commuting, because the number of jobs in each area is not necessarily the same as the number of local residents in work. GVA per filled job also adjusts for double-jobbing (when some individuals hold two or more jobs).

\section{GVA per job adjusted for industry mix}

Different industries have different levels of output per head, and the mix of industries varies from place to place. We therefore calculate what would have been each area's GVA per job if each industry in the area had the UK average GVA per job for that industry. Here we disaggregate all workplace employment into eight different industries ${ }^{3}$, again using ONS data. We then deduct the industry effect from the GVA per filled job.

\section{GVA per job adjusted for industry and occupation}

Within each industry there are 'spatial divisions of labour': managers and professionals tend to be located more in some places (e.g. London) whereas the workers undertaking routine production or delivering routine services are more prevalent elsewhere. This boosts GVA per job in the places where managers and professionals are located (because their higher pay is counted as higher output) and lowers the figures where they are a smaller proportion of the workforce. We

\footnotetext{
${ }^{3}$ SIC sections A, B, D \& E (Agriculture, Mining, Electricity, Gas, Water and Waste), C (Manufacturing), $F$ (Construction), G \& I (Retail, Distribution, Hotels and Restaurants), H \& J (Transport and Communications), K, L , M, \& N (Banking, Finance and Business services), O, P \& Q (Public administration, Education and Health), R, S \& T (Other services). So urces: Workplace employment by area, 2011 Census of Population; GVA per employee by industry 2018, ONS. Data on workplace employment by industry for later years is either subject to sampling error (APS) or omits large numbers of self-employed (Business Register and Employment Survey) and is therefore unsuitable for this exercise.
} 
calculate what would have been each area's GVA per job if each occupational group 4 within each industry had the UK average GVA for that occupation. As a proxy for GVA per person in each occupation we use UK average gross hourly earnings of employees in each occupational group from the ONS Labour Force Survey. The impact of occupational mix is the difference between the impact of industry mix (see earlier) and the expected GVA per job in each area resulting from this second calculation.

\section{'Efficiency factor'}

The final adjustment is for differences between places in average hours worked. ONS publishes data on hours worked in each area, allowing the necessary adjustment. The resulting figure is what we have termed the 'efficiency factor' - the productivity of workers in each area after having adjusted for the mix of industries, the mix of occupations and hours worked. Unlike GVA per filled job, which simply counts the value of production per worker, the 'efficiency factor' tries to measure how well the production of goods and services is carried out in each location.

At each step in this exercise the productivity in each sub-region is expressed in relation to the national average as an index number where $\mathrm{UK}=100$.

The 'efficiency factor' nevertheless comes with a health warning: these are estimates based on the cumulative effect of a number of calculations and inevitably subject to a margin of error. In particular, it is unlikely that the adjustments for industry and occupation, based on just eight industry groups and nine occupational groups, are able to take full account of each of these factors.

\section{Sub-regional differences in aggregate productivity}

Table 1 documents the differences in aggregate productivity between UK sub-regions on each of the measures described above. The sub-regions are ranked here from highest to lowest in terms of GVA per head. On this indicator London comes out on top at 177 per cent of the UK average, whereas Southern Scotland ranks lowest at just 59 per cent. To put these figures another way, output per head in London is three times higher than in Southern Scotland.

At the other end of the spectrum, the differences in estimated efficiency, in the final column, are more modest. London is overtaken at the top by Thames Valley Berkshire, at 126 per cent of the UK average, whilst Cornwall is lowest at 81 per cent. To put these figures

\footnotetext{
${ }^{4}$ (1) Managers, directors and senior officials, (2) Professional occupations, (3) Associate professional and technical occupations, (4) Administrative and secretarial occupations, (5) Skilled trades occupations, (6) Caring, leisure and other service occupations, (7) Sales and customer service occupations, (8) Process, plant and machine operatives, (9) Elementary occupations. Source: Workplace employment by area, 2011 Census of Population.
} 
Table 1: Alternative measures of productivity (GVA) by sub-region, 2018, UK=100

\begin{tabular}{|c|c|c|c|c|c|c|c|c|}
\hline & $\begin{array}{r}\text { GVA } \\
\text { per } \\
\text { head }\end{array}$ & $\begin{array}{r}\begin{array}{r}\text { less } \\
\text { imputed } \\
\text { rent }\end{array} \\
\end{array}$ & $\begin{array}{r}\text { per } 16-64 \\
\text { year old }\end{array}$ & $\begin{array}{r}\text { per } \\
\text { employed } \\
\text { resident }\end{array}$ & $\begin{array}{r}\text { per } \\
\text { filled } \\
\text { job }\end{array}$ & $\begin{array}{r}\text { less } \\
\text { industry } \\
\text { effect }\end{array}$ & $\begin{array}{r}\text { less } \\
\text { occupation } \\
\text { effect }\end{array}$ & $\begin{array}{r}\text { adjusted for } \\
\text { hours worked } \\
\text { ('efficiency factor') }\end{array}$ \\
\hline London & 177 & 178 & 166 & 167 & 141 & 134 & 125 & 116 \\
\hline Thames Valley Berkshire & 170 & 173 & 171 & 161 & 142 & 137 & 129 & 126 \\
\hline North Eastern Scotland & 131 & 134 & 128 & 122 & 116 & 112 & 113 & 108 \\
\hline Enterprise M3 & 124 & 121 & 125 & 126 & 114 & 112 & 106 & 111 \\
\hline Cheshire and Warrington & 122 & 124 & 129 & 125 & 111 & 108 & 108 & 106 \\
\hline Hertfordshire & 121 & 120 & 120 & 113 & 101 & 100 & 97 & 95 \\
\hline Coventry and Warwickshire & 109 & 111 & 110 & 108 & 105 & 104 & 104 & 106 \\
\hline Oxfordshire & 108 & 105 & 105 & 97 & 90 & 91 & 87 & 89 \\
\hline West of England & 107 & 108 & 105 & 101 & 96 & 96 & 93 & 95 \\
\hline Highlands and Islands & 106 & 106 & 109 & 90 & 90 & 95 & 100 & 105 \\
\hline Swindon and Wiltshire & 104 & 105 & 108 & 101 & 104 & 104 & 104 & 110 \\
\hline South East Midlands & 102 & 103 & 104 & 98 & 103 & 102 & 104 & 99 \\
\hline Eastern Scotland & 102 & 103 & 100 & 101 & 109 & 110 & 111 & 114 \\
\hline Buckinghamshire Thames Valley & 98 & 91 & 94 & 87 & 94 & 93 & 88 & 88 \\
\hline Greater Cambridge and Greater Peterborough & 97 & 96 & 99 & 94 & 93 & 92 & 92 & 93 \\
\hline Coast to Capital & 95 & 90 & 91 & 87 & 96 & 95 & 93 & 96 \\
\hline Greater Birmingham and Solihull & 94 & 96 & 97 & 103 & 98 & 98 & 99 & 100 \\
\hline Gloucestershire & 92 & 90 & 93 & 85 & 87 & 87 & 86 & 86 \\
\hline Greater Manchester & 89 & 90 & 89 & 93 & 90 & 90 & 91 & 92 \\
\hline East Wales & 89 & 89 & 90 & 89 & 86 & 88 & 90 & 91 \\
\hline Solent & 87 & 87 & 86 & 86 & 95 & 98 & 99 & 108 \\
\hline Leicester and Leicestershire & 86 & 87 & 86 & 88 & 92 & 93 & 96 & 96 \\
\hline Cumbria & 84 & 83 & 88 & 84 & 81 & 83 & 88 & 91 \\
\hline Dorset & 84 & 80 & 86 & 81 & 81 & 83 & 83 & 86 \\
\hline Leeds City Region & 84 & 85 & 85 & 87 & 86 & 87 & 88 & 88 \\
\hline York, North Yorkshire and East Riding & 83 & 81 & 85 & 82 & 81 & 84 & 85 & 87 \\
\hline West Central Scotland & 83 & 85 & 81 & 90 & 90 & 92 & 94 & 94 \\
\hline Lancashire & 80 & 81 & 83 & 84 & 89 & 92 & 95 & 96 \\
\hline Worcestershire & 80 & 78 & 82 & 78 & 81 & 81 & 83 & 83 \\
\hline New Anglia & 80 & 79 & 84 & 81 & 84 & 86 & 89 & 94 \\
\hline Northern Ireland & 79 & 79 & 79 & 85 & 89 & 93 & 96 & 91 \\
\hline South East & 78 & 74 & 77 & 74 & 86 & 88 & 90 & 93 \\
\hline Derby, Derbyshire, Nottingham and Nottinghamshire & 77 & 78 & 78 & 79 & 85 & 87 & 90 & 92 \\
\hline The Marches & 76 & 75 & 78 & 75 & 77 & 79 & 82 & 83 \\
\hline Humber & 76 & 77 & 79 & 81 & 85 & 87 & 94 & 94 \\
\hline Liverpool City Region & 76 & 77 & 77 & 81 & 90 & 94 & 98 & 100 \\
\hline Heart of the South West & 73 & 71 & 75 & 71 & 74 & 78 & 81 & 86 \\
\hline Stoke-on-Trent and Staffordshire & 73 & 74 & 75 & 73 & 81 & 84 & 88 & 89 \\
\hline North East & 72 & 73 & 73 & 77 & 84 & 87 & 92 & 94 \\
\hline Greater Lincolnshire & 72 & 72 & 75 & 75 & 81 & 84 & 90 & 91 \\
\hline Tees Valley & 71 & 72 & 74 & 82 & 89 & 92 & 97 & 99 \\
\hline Sheffield City Region & 69 & 70 & 70 & 72 & 80 & 83 & 88 & 90 \\
\hline Cornwall and Isles of Scilly & 68 & 64 & 69 & 66 & 69 & 74 & 78 & 81 \\
\hline West Wales and The Valleys & 63 & 63 & 66 & 69 & 79 & 85 & 90 & 91 \\
\hline Black Country & 62 & 63 & 64 & 71 & 79 & 81 & 86 & 85 \\
\hline Southern Scotland & 59 & 58 & 60 & 61 & 75 & 79 & 86 & 88 \\
\hline United Kingdom & 100 & 100 & 100 & 100 & 100 & 100 & 100 & 100 \\
\hline
\end{tabular}

Sources: ONS and Sheffield Hallam University 
another way, the lowest ranked UK sub-region has an estimated efficiency of production that is just below two-thirds of the best. 'Efficiency', as measured here, is an estimate of productivity after adjusting for population and commuting, for industrial and occupational mix and for hours worked. It tries to measure how well productive tasks are undertaken in each part of the country.

GVA per filled job (in the fifth column of numbers) falls between the two extremes. On this measure Thames Valley Berkshire comes in at 142 per cent of the UK average, closely followed by London at 141 per cent, with Heart of the South West bringing up the rear at 74 per cent - an almost two-fold difference between top and bottom. GVA per filled job does not however adjust for the mix of industries, occupations or hours worked.

The key point to note from Table 1 is that there are substantial variations in aggregate productivity across UK sub-regions - a widely accepted observation - but that in terms of the efficiency of production the differences appear to be much smaller. This is a reaffirmation of the conclusion from our 2019 study but using more up-to-date data.

\section{Disaggregating by industry: data issues}

A digression about data is necessary at this point. The accurate measurement of output (GVA) at the local scale is inherently difficult. GVA is itself the result of a calculation - the value of finished outputs minus the value of bought-in inputs - and in sectors where a high proportion of transactions are in cash there may be under-recording. In non-market sectors, such as public services, outputs are particularly hard to measure, lead ing to reliance on the measurement of inputs such as wages and salaries. GVA then needs to be allocated to specific places, which is not easy for multi-site businesses. The upshot is that GVA data for local areas is likely to be subject to a margin of error.

In the case of overall measures of productivity at the sub-regional scale the margin of error is unlikely to be large and in any case the differences between sub-regions are sufficiently big for distortions to the overall pattern to be unlikely. There are nevertheless some odd figures. Between 2017 and 2018, for example, the data from ONS points to a surge in GVA per head in Thames Valley Berkshire, from 153 per cent of the UK average to 170 per cent, and to corresponding large falls in neighbouring Oxfordshire and Buckinghamshire Thames Valley. Real changes of this magnitude over the course of a year seem unlikely. Likewise, there were substantial discontinuities in the data for some Scottish sub-regions between 2016 and 2017, probably triggered by the introduction of new NUTS2 boundaries.

Disaggregating productivity databy industry adds further complications. In the figures presented here we have combined the GVA data by industry and sub-region, published by ONS, with employment data by industry and sub-region from the Business Register and Employment Survey (BRES), complied separately by ONS. That the two data sources have been assembled separately is a potential source of inconsistency and the BRES employment data in any case omits the self-employed that are not registered for VAT. Furthermore, both datasets allocate output and employment to narrowly-defined industries, which is potentially problematic where businesses operate at the boundaries between sectors or straddle two or more activities. In practice, the fine detail of the resulting data on 
productivity by sector by sub-region suggests that distortions of this kind have occasionally crept in.

In the analysis that follows we have taken the figures on production an d employment produced by the Office for National Statistics at face value, knowing full well that they generate a number of odd observations. The important point is that too much weight should not be placed on any of the individual figures we present, or on small differences. The contrasts between industries and places are however generally large enough to point to realworld differences.

\section{Differences in productivity between industries}

Table 2 shows the GVA per job, relative to the average for the economy as a whole, in each sector of the UK economy. The sectors are ranked from highest to lowest and the table also shows the total employment in each sector.

Table 2: UK productivity by sector, 2018

\begin{tabular}{lrr}
\hline & $\begin{array}{r}\text { GVA per job } \\
\text { UK=100 }\end{array}$ & Employment \\
\hline Real estate & 242 & 590,000 \\
Finance \& insurance & 236 & $1,050,000$ \\
Information \& communication & 190 & $1,300,000$ \\
Construction & 140 & $1,530,000$ \\
Manuf acturing & 138 & $2,520,000$ \\
Agriculture, mining, energy \& water & 137 & 920,000 \\
Public administration \& defence & 126 & $1,330,000$ \\
Professional, scientific \& technical activities & 101 & $2,720,000$ \\
Transport \& storage & 98 & $1,480,000$ \\
Other services & 87 & 650,000 \\
Wholesale, retail \& motor trade & 78 & $4,790,000$ \\
Education & 74 & $2,700,000$ \\
Arts, entertainment \& recreation & 73 & 780,000 \\
Administrative \& support services & 67 & $2,780,000$ \\
Health \& social work & 65 & $4,090,000$ \\
Accommodation \& food services & 41 & $2,370,000$ \\
& & \\
UK & 100 & $31,580,000$ \\
\hline
\end{tabular}

Sources: ONS and BRES 
At the top of the table, real estate ${ }^{5}$ and financial services have a GVA per job that is more than double the UK average. At the bottom, accommodation and food services have a GVA per job that is less than half the national average.

The important observation is that at the national scale there are big differences in productivity (measured by GVA per job) between industries, which underlines the point that the mix of industries in each locality is likely to be an important influence on overall aggregate productivity for the area, as the calculations in Table 1 demonstrated for UK subregions.

Some of the differences between industries will of course reflect the extent of part-time working. Accommodation and food services, for example, employs large numbers of parttime staff, which will help explain its low GVA per job. Low wages and part-time working will also help explain the low GVA per job in health and social work.

\section{Sub-regional differences in productivity by industry}

But does the productivity of each industry vary by location? This is a crucial question, requiring the disaggregation of data by industry and sub-region - a very large matrix which we do not present here and one that in at least a few cases appears to be affected by shortcomings in the base data. It is however possible to take an overview.

For each industry, Table 3 counts the number of UK sub-regions (there are 46 in all) that have a GVA per job within 10 per cent and 20 per cent of the UK average for that industry. This table ranks industries from the ones with the lowest sub-regional diversity in GVA per job through to those with the greatest diversity. Overall, the figures point to substantial sub regional variations in productivity but with important differences between industries.

At the top of the table, with modest sub-regional differences, are health, education and public administration \& defence. In around half to two-thirds of all sub-regions, productivity in these three sectors is within 10 per cent of the national average, and in around nine out of ten sub-regions it is within 20 per cent. The distinguishing feature of the three sectors is of course that they are dominated by the public sector and in theory they should provide a broadly similar standard of service across the whole country. The way a school or hospital is organised, and the type of the staff it employs, is unlikely to differ radically from one part of the country to another so it is unsurprising that productivity in these sectors does not vary a great deal from place to place. Where there is variation, the rather higher GVA per job in some cities and the lower figure in some rural areas suggests that the location of major hospitals and universities is a contributory factor.

Accommodation \& food services, retailing and construction also display relatively modest differences in productivity across the country, with around three-quarters of sub-regions within 20 per cent of the national average. This is again not difficult to explain because the way a hotel, a pub, a shop or a building site is organised seems unlikely to vary much across the country. There are common standards that most businesses in these sectors will follow

\footnotetext{
${ }^{5}$ The figures for output in this sector exclude imputed rent.
} 


\begin{tabular}{lrr}
\hline & $\begin{array}{r}\text { Within } \begin{array}{r}\text { 10\% of UK } \\
\text { average }\end{array} \\
\text { No. of sub-regions } \\
\text { (UK } n=46)\end{array}$ & $\begin{array}{r}\text { Within 20\% of UK } \\
\text { averag }^{\star}\end{array}$ \\
$\begin{array}{r}\text { No. of sub-regions } \\
\text { (UK } n=46)\end{array}$ \\
\hline Health \& social work & 31 & 44 \\
Education & 27 & 39 \\
Public administration \& defence & 21 & 41 \\
Accommodation \& food services & 21 & 36 \\
Manuf acturing & 20 & 29 \\
Wholesale, retail \& motor trade & 19 & 34 \\
Construction & 16 & 32 \\
Other services & 12 & 31 \\
Transport \& storage & 12 & 30 \\
Real estate & 12 & 29 \\
Agriculture, mining, energy \& water & 10 & 23 \\
Administrative \& support services & 10 & 22 \\
Finance \& insurance & 9 & 13 \\
Arts, entertainment \& recreation & 6 & 14 \\
Information \& communication & 5 & 17 \\
Professional, scientific \& technical & 5 & 15 \\
\hline
\end{tabular}

*UK average GVA per job for each sector Sources: ONS and BRES

and many of the bigger employers operate across the whole country, presumably with similar technology, management and skills.

At the bottom of the table there are a number of sectors in which there are clearly very large sub-regional variations in productivity - finance, arts \& entertainment, information \& communication, and professional services. In these sectors fewer than one in five subregions have productivity within 10 per cent of the national average, and only a third within 20 per cent. A possibility here is that in looking at the differences between sub-regions we are not necessarily comparing like-with-like. London's financial sector, for example, includes high value-added investment banking (in monetary terms, even if its social value is sometimes questioned) whereas finance in much of the rest of the country comprises little more than high-street retail banking, back offices and call centres. London and a handful of other cities also have high-end jobs in law, property, the media, and head offices that are not found in large numbers in other places.

Overall, however, it is difficult to escape the conclusion that aside from the public sector there are substantial sub-regional variations in productivity within industries. To illustrate this point, Table 4 shows the data for manufacturing. In this sector, GVA per job varies from 241 per cent of the UK average in Cheshire \& Warrington through to just 51 per cent in the Black Country. Concerningly too, the sub-regions with the very lowest GVA per job - Stoke \& 


\begin{tabular}{|c|c|c|}
\hline & $\begin{array}{r}\text { GVA per job } \\
\text { UK=100 }\end{array}$ & Employment \\
\hline Cheshire \& Warrington & 241 & 41,500 \\
\hline Hertfordshire & 157 & 34,500 \\
\hline Thames Valley Berkshire & 151 & 25,500 \\
\hline Highlands \& Islands & 148 & 14,500 \\
\hline Coast to Capital & 146 & 42,500 \\
\hline Swindon \& Wiltshire & 145 & 29,500 \\
\hline Oxfordshire & 139 & 26,500 \\
\hline Coventry \& Warwickshire & 134 & 55,500 \\
\hline Enterprise M3 & 129 & 44,000 \\
\hline Greater Birmingham \& Solihull & 121 & 92,000 \\
\hline Liverpool City Region & 120 & 49,000 \\
\hline North Eastern Scotland & 116 & 22,500 \\
\hline East Wales & 110 & 63,000 \\
\hline Eastern Scotland & 110 & 62,500 \\
\hline Greater Cambridge and Greater Peterborough & 104 & 85,000 \\
\hline South East & 102 & 107,500 \\
\hline The Marches & 101 & 38,500 \\
\hline South East Midlands & 101 & 92,500 \\
\hline Lancashire & 99 & 87,500 \\
\hline Northern Ireland & 99 & 86,000 \\
\hline West of England & 98 & 36,000 \\
\hline West Central Scotland & 97 & 47,000 \\
\hline London & 96 & 114,500 \\
\hline North East & 95 & 90,500 \\
\hline Humber & 95 & 68,500 \\
\hline New Anglia & 94 & 66,500 \\
\hline West Wales \& the Valleys & 93 & 82,500 \\
\hline Leicester \& Leicestershire & 92 & 59,500 \\
\hline Southern Scotland & 91 & 34,500 \\
\hline Greater Manchester & 91 & 104,500 \\
\hline Cumbria & 90 & 37,500 \\
\hline Gloucestershire & 90 & 34,500 \\
\hline York, $\mathrm{N}$ Yorkshire and E Riding & 86 & 56,000 \\
\hline Dorset & 86 & 29,000 \\
\hline Tees Valley & 84 & 25,000 \\
\hline Greater Lincolnshire & 83 & 67,000 \\
\hline Buckinghamshire Thames Valley & 83 & 17,500 \\
\hline Derby, Derbyshire, Notting ham, Notts & 82 & 126,500 \\
\hline Leeds City Region & 80 & 150,000 \\
\hline Worcestershire & 77 & 34,000 \\
\hline Heart of the South West & 76 & 70,500 \\
\hline Cornwall \& Isles of Scilly & 76 & 15,500 \\
\hline Stoke \& Staffordshire & 71 & 63,000 \\
\hline Solent & 69 & 45,000 \\
\hline Sheffield City Region & 67 & 92,500 \\
\hline Black Country & 51 & 65,500 \\
\hline All manufacturing & 100 & $2,520,000$ \\
\hline
\end{tabular}

Sources: ONS and BRES 
Staffordshire, Solent, Sheffield City Region and the Black Country - are parts of the country where manufacturing remains a major component of the local economy.

Manufacturing is of course a diverse sector, covering both labour and capital-intensive industries and a wide range of products. A suspicion must be that part of what can be observed in the disparities in productivity at the sub-regional scale reflects the local mix of manufacturing industries. Cheshire \& Warrington, for example, covers a number of capitalintensive chemical plants. Another group of sub-regions - Swindon \& Wiltshire, Oxfordshire, Coventry \& Warwickshire, Greater Birmingham \& Solihull and Liverpool City Region include high-productivity, capital-intensive car assembly plants that will boost the average for the sub-region as a whole.

The local mix of manufacturing industries may however offer only a partial explanation. To illustrate this point, Table 5 breaks down the figures for productivity in manufacturing into four broad industrial groups within the sector 6 . Again, the table show the numbers of subregions in which productivity (GVA per job) is within 10 per cent and 20 per cent of the UK average for that industrial group.

If industry mix is at the root of the large variation in overall manufacturing productivity between sub-regions, we might expect to see rather less local variation within component parts of the manufacturing sector. In fact, Table 5 shows this is not the case: there is if anything rather more divergence in sub-regional levels of productivity within each of these four component parts of manufacturing than within the manufacturing sector as a whole.

Table 5: Sub-regional variation productivity within manufacturing groups, 2018

\begin{tabular}{|c|c|c|}
\hline & $\begin{array}{r}\text { Within } 10 \% \text { of UK } \\
\text { average }^{*}\end{array}$ & $\begin{array}{r}\text { Within } 20 \% \text { of UK } \\
\text { average }\end{array}$ \\
\hline & $\begin{array}{r}\text { No. of sub-regions } \\
(\mathrm{UK} n=46)\end{array}$ & $\begin{array}{r}\text { No. of sub-regions } \\
(U K n=46)\end{array}$ \\
\hline Food, beverages, textiles \& clothing & 13 & 24 \\
\hline Wood, petroleum, chemicals \& minerals & 7 & 17 \\
\hline Metals, electrical products \& machinery & 10 & 25 \\
\hline Other manuf acturing, repair \& installation & 13 & 26 \\
\hline All manufacturing & 20 & 29 \\
\hline
\end{tabular}

*UK average GVA per job within each group Sources: ONS and BRES

${ }^{6}$ This is the most detailed breakdown that the published GVA statistics by industry and sub-region will allow. 


\section{Comparing highest and lowest}

Another way of exploring the relationship between productivity and location is to look more closely at the sub-regions with the highest and lowest overall levels of productivity. Is higher or lower level of productivity in these places consistent across industries, or is it confined to specific sectors?

Table 6 looks at productivity in six sub-regions ${ }^{7}$. At the top end of the scale:

- London, which has the highest GVA per job, at 143 percent of the UK average

- Thames Valley Berkshire, which has the second highest GVA per job, at 141 per cent of the UK average

- Enterprise M3, which extends from Surrey into Hampshire, and has the third highest at 129 per cent

And at the bottom in terms of overall productivity:

- West Wales \& the Valleys, at 77 per cent of the UK average GVA per job

- Cornwall \& the Isles of Scilly, at 74 per cent

- Southern Scotland, at 72 per cent, the lowest in the UK

The top half of the table shows GVA per job in the local economy broken down into eight broad sectors. The striking feature on this measure is that high or low levels of productivity appear to be consistent across most sectors. London's high figure, for example, is not just rooted in high value-added in financial and professional services but can also be observed in construction, in transport \& communications, in distribution, hotels \& restaurants, in 'other services' and even in public services, though not in manufacturing. In West Wales \& the Valleys, Cornwall and Southern Scotland, all sectors of the local economy have below average GVA per job.

The bottom half of the table adjusts for the local mix of occupations. This part of the table replicates the calculation earlier for sub-regional economies as a whole by estimating what would have been the GVA per job if each occupational group within each industry had the UK average GVA for that occupation, and uses UK average gross hourly earnings by occupation as a proxy for GVA. In effect, this calculation adjusts for the concentration within each sector of higher-paid white-collar jobs in places such as London and the predominance of lower-paid routine production and service jobs in other places.

\footnotetext{
7 The GVA per job figures here differ very slightly from those in Table 1, which use ONS estimates of total employment, because they use BRES employment data (which has small omissions) in order to allow the differences between industries to be explored.
} 
Table 6: GVA per job by industry: ‘high' and 'low' sub-regions, 2018, UK=100

\begin{tabular}{|c|c|c|c|c|c|c|}
\hline & London & $\begin{array}{r}\text { Thames } \\
\text { Valley } \\
\text { Berkshire }\end{array}$ & $\begin{array}{r}\text { Enterprise } \\
\text { M3 }\end{array}$ & $\begin{array}{r}\text { West Wales } \\
\& \text { Valleys }\end{array}$ & Cornwall & $\begin{array}{l}\text { Southem } \\
\text { Scotland }\end{array}$ \\
\hline Agriculture, energy etc. & 158 & 217 & 249 & 54 & 89 & 83 \\
\hline Manuf acturing & 96 & 151 & 129 & 93 & 76 & 91 \\
\hline Construction & 143 & 109 & 135 & 73 & 86 & 67 \\
\hline Retail, hotels etc. & 120 & 142 & 150 & 77 & 75 & 73 \\
\hline Transport \& comm. & 154 & 178 & 132 & 78 & 54 & 67 \\
\hline Finance \& professional & 151 & 112 & 127 & 67 & 74 & 64 \\
\hline Public admin etc. & 124 & 110 & 103 & 89 & 88 & 70 \\
\hline Other services & 144 & 97 & 115 & 75 & 70 & 61 \\
\hline All industries & 143 & 141 & 129 & 77 & 74 & 72 \\
\hline \multicolumn{7}{|c|}{ Adjusted for occupational mix } \\
\hline Agriculture, energy etc. & 149 & 207 & 240 & 59 & 95 & 90 \\
\hline Manuf acturing & 91 & 138 & 120 & 98 & 80 & 97 \\
\hline Construction & 140 & 105 & 131 & 77 & 89 & 72 \\
\hline Retail, hotels etc. & 116 & 138 & 148 & 79 & 73 & 75 \\
\hline Transport \& comm. & 146 & 163 & 119 & 87 & 61 & 78 \\
\hline Finance \& professional & 142 & 109 & 124 & 75 & 79 & 74 \\
\hline Public admin etc. & 118 & 107 & 102 & 92 & 90 & 74 \\
\hline Other services & 136 & 96 & 115 & 78 & 71 & 66 \\
\hline All industries & 135 & 135 & 125 & 81 & 78 & 78 \\
\hline
\end{tabular}

Sources: ONS and BRES

This adjustment for occupational mix narrows the gap in productivity between places, as Table 1 demonstrated earlier, but it still leaves a broadly similar pattern - the places with high overall productivity still record high productivity across most secto rs, whilst the places with low overall productivity still display lower productivity across most or all sectors. As in Table 1, however, there are limitations to this adjustment. Based on just nine occupational groups, it is unlikely to adjust fully for the concentration of the very highest-grade jobs (with the highest pay and highest GVA) in places such as London.

The average number of hours worked will also influence comparisons between places but there is no data available by industry and locality to enable a reliable adjustment for this factor. As Table 1 showed, an adjustment for hours worked makes an important difference to the aggregate figures for London, where the proportion of part-time jobs is smaller than elsewhere, reducing its productivity advantage by nine percentage points. Conversely, productivity in West Wales \& the Valleys, in Cornwall and in Southern Scotland is boosted a little by an adjustment for hours worked. However, these adjustments still leave large gaps in local productivity. 


\section{England's city regions}

Table 7 presents figures on GVA per job by industry in each of England's eight main city regions outside London ${ }^{8}$. The city regions are arranged from left to right according to their overall level of GVA per job.

All these city regions have an overall GVA per job below the UK average, ranging from 98 per cent of the average in Greater Birmingham \& Solihull through to 79 per cent in Sheffield City Region. This is partly a reflection of the way in which the size and huge lead of London (at 143 per cent) drags up the UK average but it also indicates that the city regions away from the capital are not especially impressive in terms of productivity. This lacklustre productivity, relative to the UK average, is evident in most sectors in most of the city regions.

What is also noticeable, however, is that there is substantial diversity in GVA per job between sectors in each of the city regions. A few sectors are well ahead of the UK average; others in the same place lag badly behind.

In Greater Birmingham \& Solihull, for example, manufacturing productivity comes in at 120 per cent of the UK average but finance and professional services at just 83 per cent. In Liverpool City Region the gap is even larger - 120 per cent in manufacturing, 75 per cent in finance and professional services. In West of England (the Bristol area) the gap is smaller but the other way round - 98 per cent in manufacturing, 106 per cent in finance and professional services. In Sheffield City Region manufacturing only reaches 67 per cent of the UK average but construction 96 per cent.

The sector that shows the least variation in GVA per job between city regions is public administration, education and health, which varies from 104 per cent of the UK average in Greater Manchester to 90 per cent in North East England (the Newcastle area). This underlines the observation earlier, based on Table 2 , that these mainly public services display only modest variation in productivity across the country.

\section{Assessment}

The evidence on the variations in productivity between industries and places is complex and does not lend itself to a single explanation. More plausibly, what can be observed is the net effect of a number of factors that do not always work in the same direction.

The most important and clearest-cut observation is that, in aggregate, the differences in the efficiency of production across the country appear to be far smaller than the differences in productivity measured by GVA per head or GVA per job. A substantial part of the differences between places in GVA per job is attributable to the mix of industries, the mix of occupations and the numbers of hours worked.

\footnotetext{
${ }^{8}$ These are LEP areas and do not in all cases coincide with the boundaries of combined authorities.
} 
Table 7: GVA per job by industry in England's main city regions outside London, 2018, UK=100

\begin{tabular}{|c|c|c|c|c|c|c|c|c|}
\hline & $\begin{array}{r}\text { Greater } \\
\text { Birmingham } \\
\& \text { Solihull }\end{array}$ & $\begin{array}{l}{ }^{*} \text { West of } \\
\text { England }\end{array}$ & $\begin{array}{r}\text { Greater } \\
\text { Manchester }\end{array}$ & $\begin{array}{r}\text { Liverpool } \\
\text { City } \\
\text { Region }\end{array}$ & $\begin{array}{r}\text { Leeds } \\
\text { City } \\
\text { Region }\end{array}$ & ${ }^{* \star D 2 N 2}$ & $\begin{array}{r}{ }^{* * *} \text { North } \\
\text { East }\end{array}$ & $\begin{array}{r}\text { Sheffield } \\
\text { City } \\
\text { Region }\end{array}$ \\
\hline Agriculture, energy etc. & 90 & 107 & 108 & 113 & 121 & 100 & 120 & 83 \\
\hline Manuf acturing & 121 & 98 & 91 & 120 & 80 & 82 & 95 & 67 \\
\hline Construction & 102 & 98 & 89 & 100 & 96 & 86 & 70 & 96 \\
\hline Retail, hotels etc. & 110 & 94 & 88 & 84 & 91 & 95 & 79 & 91 \\
\hline Transport \& comm. & 85 & 79 & 77 & 91 & 68 & 77 & 80 & 64 \\
\hline Finance \& professional & 83 & 106 & 79 & 75 & 78 & 75 & 76 & 66 \\
\hline Public admin etc. & 100 & 99 & 104 & 97 & 95 & 92 & 90 & 98 \\
\hline Other services & 107 & 97 & 102 & 83 & 91 & 75 & 86 & 79 \\
\hline All industries & 98 & 97 & 88 & 88 & 86 & 85 & 84 & 79 \\
\hline
\end{tabular}

*Bristol area

${ }^{*}$ Derby, Derbyshire, Notting ham, Nottinghamshire

${ }^{* * *}$ Newcastle area

Sources: ONS and BRES 
Digging deeper into the data, industry by industry and place by place, measurement issues suggest that not too much weight should be placed on small differences or individual figures. Nevertheless, there are clear patterns. One is that there is substantial diversity in the productivity of industries and sectors at the sub-regional scale. Another is that the places with the highest and lowest overall productivity (measured by GVA per job) appear to have consistently above or below average productivity across most of their local econo my. Whilst the local occupational mix and the number of hours worked can go some way towards accounting for these differences, large gaps in productivity still remain.

Four factors may explain why productivity in some industries and in some places is apparently much higher than in others.

The first is the balance of sectors within broader industrial categories. For example, take London's high GVA per job in transport \& communications (154 per cent of the UK average) compared to Sheffield City Region's much less impressive figure (64 per cent). 'Transport \& communications' is actually a diverse grouping. In London it includes 37,000 jobs in air transport and 59,000 in publishing, compared to just 250 and 900 jobs in the same sectors in Sheffield City Region. On the other hand, Sheffield City Region has 18,000 jobs in warehousing \& storage and 19,000 in land transport that fall within the same broad industrial category ${ }^{9}$. The GVA per job in these sectors is likely to differ a great deal making it hard to conclude that in transport \& communications the gap in efficiency between the two subregions is necessarily as large as the figures suggest. Sheffield City Region's specialisation in low value-added logistics is likely to drag down its productivity figures even if the city region performs this activity rather well.

The second factor is the diversity within sectors. We noted earlier that 'finance' disguises the concentration of high value-added investment banking in London and the prevalence of lower value-added retail banking elsewhere. Even sectors such as health and education, which show some of the smallest sub-regional variations in productivity, are not quite the same everywhere - the major teaching hospitals and the big universities are not evenly distributed across the country. At the local scale, this will feed through to GVA per job in these sectors. The manufacturing sector, of course, is extremely varied and even breaking it up into four component parts (in Table 5 earlier) does not do justice to its diversity and the potential impact on local measures of productivity.

The third factor is wage levels. High productivity allows high wages, but high wages can also result in high recorded productivity. For example, in parts of the service sector where it is difficult to quantify output, wages and salaries are a key element in measuring the value of production. More generally, in places and sectors that for whatever reason are relatively insulated from competition, higher wages can be passed on as higher prices which is then recorded as higher value-added. Manufactured goods are mostly traded over long distances, limiting the extent of this effect, but this is not the case for many locally-orientated services. London has high wages - median gross earnings there were 134 per cent of the UK average in 2018 - whereas in many rural areas, in particular, wages are far lower. Earnings in Cornwall, for example, were just 79 per cent of the UK average in $2018^{10}$. Wage

\footnotetext{
${ }^{9}$ Sources: Business Register and Employment Survey data for 2018.

${ }^{10}$ Sources: Annual Survey of Hours and Earnings.
} 
differences of this magnitude are not far from the differences in GVA per job and may help explain why the high or low GVA per job recorded in some parts of the country can be found in most sectors of the local economy.

The fourth factor is the efficiency of production. How big a part this plays is unclear but the of ten large differences in productivity between places and industries seem difficult to explain solely in terms of factors such as occupational mix, industrial structure and wage levels, or indeed in terms of measurement issues. Underlying all the figures there may still be variation from place to place in the efficiency with which firms go about their business.

Quite why the efficiency of production in any given industry or occupation should vary from place to place is also unclear. One possibility is that efficiency reflects the skills and qualifications of the workforce - that where employees are highly-trained they are more productive. There is however a strong correlation between qualifications and occupation so in adjusting measures of productivity for the mix of occupations (as in Tables 1 and 6) much of the impact of skills and qualifications should be taken into account. It remains possible, of course, that within each occupation the better qualified workers are concentrated in some places rather than others and that this feeds through to productivity.

Another possibility is that the clustering of businesses in some locations makes them more productive. This idea-agglomeration economies - is widely thought to lead to higher productivity in cities, where firms benefit from access to a large pool of labour, specialist suppliers and skills, a large market, flows of information and ideas and lower transaction costs. The evidence on productivity presented here provides only patchy support for these ideas. On the one hand, London's estimated 'efficiency factor' (in Table 1) is 16 per cent above the UK average and industry-by-industry (in Table 6) London has above-average GVA per job in every sector except manufacturing. On the other hand, overall GVA per job in England's other main city regions (in Table 7) is below the UK average and there is little consistency between industries.

The important point, nevertheless, is that to interpret the large differences in productivity, measured by GVA per head or per job, as the result of equally large differences in efficiency would be incorrect.

\section{Policy implications}

The recession triggered by the coronavirus crisis will for some while result in a smaller economy in all parts of the UK. The productivity of the economy as a whole, measured by the value of output per head, will decline and if firms hang on to employees as they weather the storm then output per job is also likely to decline. However, as we noted, the post-crisis world will inherit much the same capital stock, labour force and infrastructure so there is no reason to suppose that the big differences in productivity between places will disappear even if there is some detailed re-ordering of the list.

Prior to the crisis, the UK government made a commitment to 'levelling up' the country's regions and nations and its intention to do so was re-affirmed by the Prime Minister in a June 2020 speech on recovery from the crisis. Increasingly, these regional and local gaps are 
characterised by government in terms of 'productivity' so understanding exactly what the differences in productivity actually measure, how productivity varies from industry to industry as well as from place to place, and what might be done about the gaps has clearly become central to successful policy development.

This report presents a more subtle and detailed view of productivity across the UK than has previously been available. It has three main implications for public policy.

First, 'productivity' should not be confused with 'efficiency'. There are points of overlap but if an area has low productivity, measured by GVA per head or GVA per job, this is not necessarily because production there is inefficiently organised. There are a host of structural factors at work - population structure and the employment rate, the mix of industries, occupations and hours worked for example. In fact, the estimated differences in efficiency between places are a lot smaller than the differences in GVA per head or per job. What this means in practical terms is that the best way to raise productivity in a local economy may not always be to chase ever higher efficiency but to increase the number of jobs and to generate more jobs in higher-value industries and occupations.

Indeed, whether 'productivity' measured by GVA should be such a dominant indicator of the success of a local economy is questionable. As the coronavirus crisis has made clear, some of the most valuable jobs to society, in health and social care for example, are not those that record high GVA, not least because they include many low-paid occupations. More generally, reducing unemployment can in some cases actually hold down an area's average GVA per job: the success of South Yorkshire as a growing hub for logistics and distribution (a low-wage, low GVA sector) is an example. In these cases, the new jobs are probably more important than the impact on GVA data.

Second, an understanding of the complexity of local productivity is required. It is not the case that all industries in the same place have equally high or low productivity and, even where there is some consistency, we may be observing the impact of wage levels and prices rather than output. It is also not the case that any given industry, even quite narrowly defined, is exactly the same in all places, so making comparisons in productivity between places is fraught with difficulty. Simplistic assertions, based on a cursory appraisal of aggregate statistics, are unlikely to offer a useful guide to the way forward.

Substantial research needs to underpin policy interventions to raise productivity. In our study of productivity in Sheffield City Region ${ }^{11}$, for example, we identified worryingly low GVA per job in the area's manufacturing sector. That the figures in Table 4 of the present report place Sheffield City Region second-from-bottom in a league table of manufacturing productivity adds to these concerns. However, it would be wrong to assume that this low productivity is simply a reflection of inefficiency because in a competitive market inefficiency is usually punished - firms shrink and go out of business - whereas there is clearly a substantial manufacturing sector that continues to operate across the city region. One possibility is that there are further undetected structural influences biasing the data. Another is that the city region's manufacturing firms may have come to specialise in low-productivity, labour-intensive niches in which they can successfully operate year after year. The point is

${ }^{11}$ C Beatty and S Fothergill (2020) op. cit. 
that without understanding exactly what lies behind the figures it is hard to design appropriate interventions.

Third, interventions need to be tailored, industry by industry, place by place. The complexity in patterns of local productivity and their myriad causes works against a one-sizefits-all approach to raising output, employment and efficiency. Some sectors within a local economy may not require intervention; others may justify a suite of supportive measure. Likewise, the interventions needed to support productivity in one place may not be the same as in another.

Let's be clear: the UK has large imbalances in economic prosperity that justify concerted intervention to level-up its regions and nations. This is apparent in the GVA data in the present report but it is also evident in a wide range of other socio-economic data, for example on worklessness, incomes and health. The point here is that in the less prosperous places in need of support, specific interventions in the local economy need to be informed by local knowledge and hard evidence. 


\section{CRESR}

Sheffield Hallam University

City Campus

Sheffield S1 1WB

+44(0)1142253073

e: cresr@shu.ac.uk

w: shu.ac.uk/cresr

ISBN: 978-1-84387-433-1

DOI: $10.7190 /$ cresr.2020.8227913147

\section{Sheffield $\mid$ Centre for \\ Hallam Regional Economic \\ University $\mid$ and Social Research}




\section{Sheffield Hallam University}

The productivity of industries and places

BEATTY, Christina <http://orcid.org/0000-0003-0943-9979> and FOTHERGILL, Stephen $<$ http://orcid.org/0000-0002-4201-0640>

Available from the Sheffield Hallam University Research Archive (SHURA) at:

http://shura.shu.ac.uk/26784/

\section{Copyright and re-use policy}

Please visit http://shura.shu.ac.uk/26784/ and http://shura.shu.ac.uk/information.html for further details about copyright and re-use permissions. 